\title{
Preventing laboratory-associated infections in the COVID-19 era: experience from a tertiary care infectious disease hospital in Southern Vietnam
}

Man Dinh Nguyen Huy

The Hospital for Tropical Diseases

Ngoc Nghiem My

The Hospital for Tropical Diseases

Hoang Dang Minh

Oxford University Clinical Research Unit,

Trang Nguyen Hoa

Oxford University Clinical Research Unit,

Thao Duong Thi Phuong

Oxford University Clinical Research Unit,

Hang Vu Thi Ty

Oxford University Clinical Research Unit,

Tan Le Van

Oxford University Clinical Research Unit,

Nga Nguyen Thi Quynh

The Hospital for Tropical Diseases

Dung Nguyen Thanh

The Hospital for Tropical Diseases

Hung Le Manh

The Hospital for Tropical Diseases

Thai Pham Quang

National Institute of Hygiene and Epidemiology, Hanoi, Vietnam

Chau Nguyen Van Vinh

The Hospital for Tropical Diseases

Guy Thwaites

Oxford University Clinical Research Unit, Vietnam

Marc Choisy

Oxford University Clinical Research Unit, Vietnam

Motiur Rahman ( $\triangle$ mrahman@oucru.org)

Oxford University Clinical Research Unit, Vietnam https://orcid.org/0000-0002-6702-5355

\section{Method Article}

Keywords: COVID-19, SARS CoV-2, Laboratory-associated infection, Biosafety, Vietnam, Laboratory

Posted Date: December 2nd, 2020

DOI: https://doi.org/10.21203/rs.3.rs-100413/v2

License: @ (i) This work is licensed under a Creative Commons Attribution 4.0 International License. Read Full License 


\section{Abstract}

Objectives: Laboratory staff is at higher risk of coronavirus disease 2019 (COVID-19) infection owing to the handling of patient samples. Severe Acute Respiratory Syndrome Coronavirus 2 (SARS-CoV-2) focus risk assessment and risk management are essential for preventing laboratory acquired infections (LAls). We present herein the steps taken to prevent LAls related to SARS-CoV-2 testing from February 1, 2020 to September 17, 2020 in a tertiary care hospital in Vietnam.

Results: A SARS-CoV-2-focused risk assessment was conducted for laboratory processes. Risk management strategies, including engineering, administrative and operations control procedures, were established. This includes the use of dedicated facility, instrument, and cold chain units for testing; SOPs; training (testing, decontamination and cleaning staff); the introduction of biosafety level $2^{+}$laboratory practices; COVID-19 symptom reporting; enhanced cleaning protocols; and the assigning of additional staff for testing and safety system implementation. In total, 38,377 (daily mean and range: 166; $3-2,377$ ) samples were received and tested. The turnaround time (median \pm standard deviation (SD)) was $3.54 \pm 2.97$ days. Altogether, 32 staff members were involved with SARS-CoV-2 testing and biosafety management, and there were no reports of COVID-19 symptoms among them.

\section{Introduction}

On January 30, 2020, the World Health Organization declared coronavirus disease 2019 (COVID-19) a public health emergency of international concern [1]. During the ongoing COVID-19 pandemic, health-care workers (HCW), including laboratory workers, are at a substantially increased risk of becoming infected with Severe Acute Respiratory Syndrome Coronavirus 2 (SARS-CoV-2) due to direct possible contact with COVID-19 patient samples [2, 3]. This risk has been increased by the need to rapidly scale up testing facilities by recruiting new staff, (e.g., newly qualified students or laboratory technicians) to the laboratory workforce in response to the pandemic $[4,5]$.

Laboratory personnel can be exposed to SARS-CoV-2 through i) clinical specimen reception and unpacking; ii) specimen transportation to Biological Safety Level (BSL) 2 laboratories; iii) disposal of items associated with specimens; iv) sample manipulation; v) sample inactivation; vi) conducting the assays; vii) laboratory surfaces contamination, and viii) waste disposal [6]. Laboratory staff can acquire SARS-CoV-2 at work through direct or indirect contact with infected patient samples or other health-care workers or as a result of ongoing community transmission [1, 6-9]. To prevent laboratory-acquired COVID-19 infection, several guidelines have been issues by The World Health Organization, US CDC and individual countries [10,11]. These guidelines have provided a framework for primary and secondary containment requirements, personal protective equipment (PPE), and laboratory practices to prevent laboratory-acquired infections (LAls). However, it is necessary to conduct a risk assessment of laboratory processes and workflow to develop a risk management strategy for each laboratories to ensure biosafety for SARS-CoV-2 testing. In Vietnam, real-time PCR (RT-PCR) assay is assigned as a confirmatory test for SARS-CoV-2 diagnosis [12]. Two swabs are collected (one nasopharyngeal and one throat) from each patient and stored in viral transport media (VTM) at $4^{\circ} \mathrm{C}$ before sending to the laboratory [13]. Herein, we present the biosafety risk assessment and management strategies implemented in SARS-CoV-2 testing at the Hospital for Tropical Diseases, Ho Chi Minh City (HCMC), Vietnam during the first 8 months of the COVID-19 epidemic.

\section{Methods}

We report a prospective, descriptive documentation on the biosafety management of SARS-CoV-2 testing and the number of samples received and tested from February 1 to September 17, 2020 in the Molecular Diagnostic Laboratory (MDL) of the Hospital for Tropical Diseases (HTD) and Oxford University Clinical Research Unit (OUCRU), HCMC, Vietnam. The HTD is a 650-bed infectious disease hospital and a designated care provider for COVID-19 patients and a SARSCoV-2 RT-PCR testing centre for the central and south of Vietnam. HTD, in partnership with OUCRU, maintains clinical and research laboratories including a BSL2 clinical laboratory (ISO 15189 certified), a BSL2 research laboratory (Good Clinical Laboratory Practice (GCLP)-compliant and Ministry of Health (MoH)certified BSL2) and a BSL3 and Specified Animal Pathogen Order 4 (SAPO4) laboratory (MoH-certified) [14].

A SARS-CoV-2-focused risk assessment of all laboratory processes (pre-analytic, analytic and post-analytic) was conducted and a risk management strategy was developed and implemented. Standard Operation Procedures (SOP) for laboratory processes were developed and staff were trained. Daily self-reporting of COVID-19 symptoms (fever, cough, sore throat and similar symptoms of any family member) was implemented and symptom reporting was analysed. Biosafety compliance monitoring was implemented. The laboratory certification for SARS-CoV-2 testing and biosafety was conducted by the Department of Health (DoH) and CDC. An external quality assurance programme, including inter-laboratory comparisons, was implemented to ensure the quality of testing. A laboratory logistic and PPE stock monitoring system, including minimum stock for reordering, was implemented to ensure availability of stocks.

We extracted data from the hospital database and analysed using Statistical Package for Social Science (SPSS) software (IBM SPSS Statistics 23, NY USA). We analysed the data for the number of samples received daily, samples rejected, the samples tested or, sent to other laboratories. Turnaround time was calculated by subtracting the sample receiving date and time to the report delivery date and time. The total number of samples tested for COVID-19 in HCMC and the COVID-19 outbreak information data were collected from the National COVID-19 database maintained by the National Institute of Hygiene and Epidemiology (NIHE).

\section{Results}

The SARS-CoV-2 focused risk assessment includes pre-analytic (sample handling after receiving, acceptance criteria assessment, and organizing samples for analytic process), analytic (sample inactivation, nucleic acid extraction and RT-PCR assay) and post-analytic (data retrieval, reporting, and storage or destruction of samples) processes. Risk management includes engineering (infrastructure, facility, workflow, primary and secondary containment), administrative (SOPs, PPE, and disinfectants), operational process controls (training, facility decontamination, waste management, LAl reporting, logistics, and safety compliance monitoring), and monitoring of the implementation (Table 1).

Page 2/9 
As a part of the risk management strategy, HTD and OUCRU shared the laboratory infrastructure and facilities (e.g., specimen reception room, cold chain units, MDF, BSL3 laboratory), instruments, logistics, human resource and safety system implementation. Risk management includes the spraying of sample containers (outer containers) with freshly prepared disinfecting solution (chlorine $5000 \mathrm{ppm}$ ) and opening secondary containers in biosafety cabinets (BSC) Class $(\mathrm{Cl})$ I to examine acceptance criteria. PPE used for sample reception area includes reusable lab coats (equivalent to AAMI level 2), surgical face masks (equivalent to American Society for Testing and Materials (ASTM) level 2), nitrile gloves, goggles, hair caps, and shoe covers. The specimen reception facility is decontaminated 3 times daily (7:00 AM, 1:00 PM and 5:00 PM) with Virkon S (Peroxygen 49.8\%, Sodium chloride $27.6 \%$; $10 \mathrm{~g} / \mathrm{L}$ ) disinfectant (10 g/L) sprayed with an ultra-low volume sprayer at a dose of 20 to $30 \mathrm{~mL} / \mathrm{m}^{2}$. Waste is stored in double bags and removed before each decontamination cycle. Samples are transported to MDL in batches in secondary container and inactivated in the BSL2 laboratory in BSC Cl I following BSL2 ${ }^{+}$laboratory practices. $\mathrm{BSL2}^{+}$laboratory practice includes disposable PPE, including fit-tested particulate respirators (equivalent to an N95 mask), long-sleeved gowns (equivalent to AAMI level 3), goggles, round caps, latex gloves and shoe covers. All aerosol generating procedures are conducted in BSCs and centrifugation in sealed buckets. The MDL was decontaminated 5 times daily (7:00 AM, 11:00 AM, 3:00 PM, 6:00 PM and 11:00 PM) with Virkon S as mentioned above. In the laboratory, all BSCs are cleaned with Surfanios (DD BioLab, Barcelona, Spain) after use and irradiated with UV light once a day for 2 hours. Waste is stored in double bags and removed before each decontamination cycle. Test results were extracted from the instruments through a laboratory information system and test reports are delivered to the CDC, Ho Chi Minh City. Remaining SARS-CoV-2 positive or negative samples were stored in the BSL3 biorepository or destroyed, respectively. The heating, ventilation and air conditioning (HVAC) system of the facility was set at $26^{\circ} \mathrm{C}$, with $8-10$ air changes per hour.

SOPs for testing including sample reception, sample inactivation, TNA extraction, and sample retention/destruction, were developed. A task specific (e.g. sample reception, sample inactivation, total nucleic acid (TNA) extraction, PT-PCR assay, facility decontamination, waste management and sample destruction) training programme was implemented for staff. The training included SARS-CoV-2 focused risk assessment, biosafety, PPE use (donning and doffing), and the assigned task. Overall, 14 clinical laboratory staff (4 staff for pre-analytic, 8 staff for analytic and 2 staff for post-analytic processes) were responsible for routine SARS-CoV-2 testing. In addition to this, 4 laboratory staff members from another hospital and 8 research laboratory staff members were involved in testing during the high sample load periods. Additionally, 6 OUCRU laboratory management staff were involved in safety process implementation. All staff reported symptom daily and during the reported period none of the staff reported any symptoms of COVID-19 and a subsequent study excluded asymptomatic infection among laboratory staff [15].

The laboratory was certified by the Department of Health (DoH), HCMC on March 14, 2020 for SARS-CoV-2 testing and a safety audit were conducted by CDC, $\mathrm{HCMC}$ in early September. As a part of inter-laboratory comparison all positive samples were retested at Pasteur institute, HCMC and no discrepancies were identified between the two laboratories. The OUCRU laboratory management conducted daily inspections of safety system implementation. For logistic management a bulk procurement for 20,000 diagnostic tests was initiated in March 2020, and procurement was continued as per need. For PPE (surgical mask, N95 mask, lab coat, gloves) disinfectants, and hand sanitizers, 3 months stock was considered sufficient.

All samples received for SARS-CoV-2 testing were registered in the laboratory database. Respiratory and oropharyngeal samples for RT-PCR were tested in $\mathrm{MDL}$, and samples for microbiology culture were performed in the BSL3 laboratory. During the reporting period, there were two local COVID-19 outbreaks. The first occurred from March 24 to April 13, 2020, mostly in Hanoi and around the north, and in Ho Chi Minh City in the south of the country. The second occurred from July 28 to August 8, 2020, mostly in and around Da Nang in the centre of the country (Fig 1). From February 1, 2020 to September 17, $2020,38,377$ samples were received for testing (Table 2), accounting for $18.6 \%(38,377 / 206,626)$ of all tests done in HCMC during the reporting period. Among these 38,377 samples, $301(0.8 \%)$ were rejected as they did not fulfil the acceptance criteria. The mean number of samples received per day was 166 , with a range of 3 to 2 ,377. The turnaround time (mean \pm SD) was $3.54 \pm 2.97$ days ( $1.30 \pm 1.23$ during the non-outbreak period and $4.55 \pm 2.99$ during the outbreak period) (Table 2). During the first (March 24 to April 13) and second (July 28 to August 8 ) outbreaks, the numbers of samples received (mean and range) were 11,904 and 14,293 , with daily numbers of $626(106-2,061)$ and 1050 (34-2,377), respectively (Fig 1, Table 2). Overall, 4,924 (12.8\%) samples were sent to other laboratories for testing during the outbreak periods (2,648 during the first and 2,276 during the second outbreak).

\section{Discussion}

COVID-19 has significantly increased the workload for laboratory staff. Most clinical laboratories are often understaffed and lacked the expertise to conduct pathogen specific risk assessment to address the safety requirements. We involved laboratory staff in the risk assessment exercise and in risk management strategy development to gain their confidence and support during the implementation. We reduced the major risks through the engineering, administrative, and operation controls, and the residual risk was addressed by laboratory practices and PPE. SOPs and training played a key role in successful implementation of the risk management strategies. OUCRU maintains a BSL3 laboratory and has developed a team of biosafety trained laboratory staff over the years. These staff played a key role in implementing biosafety and scaling up the SARS-CoV-2 testing. Additionally, OUCRU maintains a critical stock of logistics and PPEs as part of an epidemic preparedness programme. Those stocks played an important role in maintaining a constant supply of logistics and PPE. The collaboration between OUCRU and HTD in COVID-19 diagnostics was vital. OUCRU facilities (specimen reception room and MDL) and staff (research staff, laboratory safety implementation team and waste management) were assigned for testing during high sample load situations.

During the reported period, the hospital received (mean and range) 166 (3-2377) additional samples on top of their routine samples. During the outbreak period, a large number of samples was assigned to HTD, which was beyond the capacity of the hospital. We observed an increase in sample rejection during the second outbreak, which might have been due to the recruitment of new staff for sample collection or poor sample management before sending to the laboratory. The laboratory could not analyse all the samples received for testing due to the time required for sample sorting and organization in pre-analytic processes. The time for pre-analytic processing is often underestimated. Similarly, the turnaround time for testing increased during the outbreak period because the sample volume exceeded the limit of testing capacity. Therefore, a clear determination of the testing capacity before sample assignment to a laboratory is critical. 
There were several challenges in the operation including i) maintaining access control of the laboratory while samples were shipped to laboratory 24 hours, ii) training of staff members in a short time, iii) sorting and organizing of specimens sent from different sites, and iv) securing logistics for diagnostic kits, reagents, and PPE. Often, it was difficult to implement all safety measures and conduct the assigned number of tests. Infectious disease epidemics pose a significant biosafety risk and increase the probability of LAls. Pathogen-specific risk assessment and clear strategies on risk management including monitoring for LAls and support for exposed and infected laboratory workers are essential to ensure trust in the workplace.

\section{Limitations}

This is a case study and might not represent the laboratory safety implementation in all SARS-CoV-2 testing laboratories in Vietnam. We did not conducted any laboratory test to exclude asymptomatic infections, however, a subsequent study reported no evidence of healthcare associated COVID-19 infection at HTD [15].

\section{Conclusion}

Infectious disease epidemics pose a significant biosafety risk and increase the probability of LAls. Pathogen-specific risk assessment and risk management strategies should be implemented to address these risks. Clear strategies on risk management and support for exposed and infected laboratory workers are essential to ensure trust in the workplace. These management strategies should include monitoring for LAls and decision making about immediately implementing essential safety measures when necessary.

\section{Abbreviations}

\begin{tabular}{|c|c|}
\hline AAMI & Association for the Advancement of Medical Instrumentation \\
\hline ASTM & American Society for Testing and Materials \\
\hline COVID-19 & Coronavirus disease 2019 \\
\hline BSL & Biosafety level \\
\hline BSC & Biosafety cabinet \\
\hline CL & Class \\
\hline DoH & Department of Health \\
\hline GCLP & Good Clinical Laboratory Practice \\
\hline HTD & Hospital for Tropical Diseases \\
\hline HCW & Health-care workers \\
\hline IPC & infection prevention and control \\
\hline LAls & Laboratory Acquired Infections \\
\hline LIS & Laboratory information system \\
\hline $\mathrm{MoH}$ & Ministry of Health \\
\hline NIHE & National Institute of Hygiene and Epidemiology \\
\hline OUCRU & Oxford University Clinical Research Unit \\
\hline PPE & Personal protective equipment \\
\hline RT & Real-time \\
\hline SAPO & Specified Animal Pathogen Order \\
\hline SARS-CoV-2 & Severe Acute Respiratory Syndrome Coronavirus 2 \\
\hline SOP & Standard Operating Procedure \\
\hline SD & Standard deviation \\
\hline SRA & Specimen reception area \\
\hline SPSS & Statistical Package for Social Science \\
\hline
\end{tabular}




\section{Declarations}

Ethics approval and consent to participate: Not applicable. The article did not involve enrolment of any humans, animals or plants. The article describes the laboratory processes. The Hospital for Tropical Diseases ethical review committee ruled that no formal ethics approval was required for this article and waived the need for consent.

Consent for publication: Not applicable

Availability of data and materials: All data and materials used for this publication are available under the OUCRU data sharing policy and can be requested at DAC@oucru.org

Competing interests: There are no competing interests

Funding: No external funding was received for this project

Authors' contributions:

MDNH: Data collection, manuscript review, implementation; NNM: Implementation, data analysis, manuscript drafting; HDM: implementation, data collection, manuscript review; TNH: data collection and data analysis, manuscript drafting and review; TDHP: implementation, data collection and analysis, manuscript drafting; HVTT: implementation, manuscript drafting, data collection; TLV: supervision of implementation, drafting and manuscript review; NNTQ: implementation, study design, manuscript review; DNT: Study design, data collection, study supervision, manuscript review; HLM: Study design, data collection, study supervision, manuscript review; TPQ: data collection and analysis, study design, manuscript drafting; CNVV: study design, supervision, manuscript review; GT: study design, supervision, manuscript review; MC: study planning, design and manuscript drafting; MR: planning, design and manuscript drafting.

All authors have read and approved the manuscript

\section{Acknowledgements:}

This study was supported by the Oxford University Clinical Research Unit, Vietnam. We thank all members of the HTD COVID-19 laboratory team and OUCRU COVID-19 research group. We also thank all laboratories who contributed testing information in the COVID-19 test result database.

OUCRU COVID-19 Diagnostic and Lab management team: Huynh Le Anh Huy, Huynh Xuan Yen, Lam Anh Nguyet, Tran Tan Thanh, Le Nguyen Truc Nhu, Le Van Tan, Motiur Rahman, Nguyen Thi Han Ny, Nguyen Thi Kim Tuyen, Nguyen Thi Thu Hong, Le Kim Thanh, Phung Le Kim Yen, Vu Thi Ty Hang, Dang Minh Hoang, Duong Thi Phuong Thao, Nguyen Hoa Trang, Ho Van Sung, Dinh Thanh Phong, Le Pham Minh Tu, Cao Thu Thuy, and Tran Thi Bich Chieu.

HTD COVID-19 Diagnostic and Lab management team: Nguyen Van Vinh Chau, Nguyen Thanh Dung, Le Manh Hung, Dinh Nguyen Huy Man, Nguyen Thi Quynh Nga, Nghiem My Ngoc, Pham Thi Ngoc Thoa, Tran Nguyen Phuong Thao, Tran Thi Lan Phuong, Le Thi Tam Uyen, Tran Thi Thanh Tam, Bui Thi Ton That, Huynh Thi Kim Nhung, Ngo Tan Tai, and Vo Trong Vuong.

\section{References}

1. Bielicki JA, Duval X, Gobat N, Goossens H, Koopmans M, Tacconelli E, van der Werf S: Monitoring approaches for health-care workers during the COVID-19 pandemic. Lancet Infect Dis 2020.

2. Zheng L, Wang X, Zhou C, Liu Q, Li S, Sun Q, Wang M, Zhou Q, Wang W: Analysis of the infection status of the health care workers in Wuhan during the COVID-19 outbreak: A cross-sectional study. Clin Infect Dis 2020.

3. Zuckerman NS, Pando R, Bucris E, Drori Y, Lustig Y, Erster O, Mor O, Mendelson E, Mandelboim M: Comprehensive Analyses of SARS-CoV-2 Transmission in a Public Health Virology Laboratory. Viruses 2020, 12(8).

4. Dodig S, Cepelak I, Cepelak Dodig D, Laskaj R: SARS-CoV-2 - a new challenge for laboratory medicine. Biochem Med (Zagreb) 2020, 30(3):030503.

5. Iwen PC, Stiles KL, Pentella MA: Safety Considerations in the Laboratory Testing of Specimens Suspected or Known to Contain the Severe Acute Respiratory Syndrome Coronavirus 2 (SARS-CoV-2). Lab Med 2020, 51(3):239-242.

6. Wong CK, Tsang DN, Chan RC, Lam ET, Jong KK: Infection Risks Faced by Public Health Laboratory Services Teams When Handling Specimens Associated With Coronavirus Disease 2019 (COVID-19). Saf Health Work 2020.

7. Sahu AK, Amrithanand VT, Mathew R, Aggarwal P, Nayer J, Bhoi S: COVID-19 in health care workers - A systematic review and meta-analysis. Am J Emerg Med 2020, 38(9):1727-1731.

8. Sam IC, Chong J, Kamarudin R, Jafar FL, Lee LM, Bador MK, Chew YY, Tan MP, Chan YF: Providing a laboratory diagnostic service for pandemic SARSCoV-2 in a developing country. Trans $R$ Soc Trop Med Hyg 2020, 114(8):553-555.

9. Zhang DX: SARS-CoV-2: air/aerosols and surfaces in laboratory and clinical settings. J Hosp Infect 2020, 105(3):577-579. 
10. Prevention CfDCa: Guidance for General Laboratory Safety Practices during the COVID-19 Pandemic. In. Atlanta, USA: Centers for Disease Control and Prevention; 2020.

11. Organization WH: Laboratory biosafety guidance related to coronavirus disease (COVID-19). In., vol. WHO/WPE/GIH/2020.3. Geneva, Switzerland World Health Organization; 2020.

12. Ministry of Health V: Introducing covid-19 diagnosis and treatment guidelines. In., vol. 3351/QĐ-BYT Hanoi, Vietnam; 2020.

13. Ministry of Health V: Monitoring, evaluating, and supporting the COVID-19 diagnostic. In. Edited by Ministry of Health V, vol. 3981/BYT-DP Hanoi, Vietnam; 2020.

14. Wertheim HF, Puthavathana P, Nghiem NM, van Doorn HR, Nguyen TV, Pham HV, Subekti D, Harun S, Malik S, Robinson J et al: Laboratory capacity building in Asia for infectious disease research: experiences from the South East Asia Infectious Disease Clinical Research Network (SEAICRN). PLoS Med 2010, 7(4):e1000231.

15. Chau NVV, Toan LM, Man DNH, Thao HP, Lan NPH, Ty DTB, Hieu DK, Tien NTM, Ngoc NM, Hung LM et al: Absence of SARS-CoV-2 antibodies in health care workers of a tertiary referral hospital for COVID-19 in southern Vietnam. J Infect 2020.

\section{Tables}

Table 1. Overview of risk assessment and risk management for SARS-CoV-2 testing at Hospital for Tropical Disease, Ho Chi Minh City, Vietnam. 


\begin{tabular}{|c|c|c|c|c|c|c|c|}
\hline & \multicolumn{3}{|l|}{ Pre-analytic } & \multicolumn{3}{|l|}{ Analytic } & \multirow{2}{*}{$\begin{array}{l}\text { Post-analytic } \\
\text { Risk assessment }\end{array}$} \\
\hline & Risk assessment & $\begin{array}{l}\text { Risk } \\
\text { man }\end{array}$ & gement & Risk assessment & Risk & lanagement & \\
\hline \multirow[t]{6}{*}{$\begin{array}{l}\text { Engineering } \\
\text { control }\end{array}$} & \multirow{6}{*}{$\begin{array}{l}\text { 1. Clinical specimen reception: } \\
\text { i) Exposure to biohazardous } \\
\text { materials (inappropriately } \\
\text { packed or leaking } \\
\text { specimens). } \\
\text { 2. Opening/unpacking and } \\
\text { accessioning of sample: i) } \\
\text { exposure to biohazardous } \\
\text { materials (opening/unpacking } \\
\text { of specimen carrier bags, } \\
\text { contamination of } \\
\text { surfaces). } \\
\text { Sample spill: } \\
\text { Unauthorized access to } \\
\text { samples, sample loss or } \\
\text { theft. }\end{array}$} & \multicolumn{2}{|c|}{$\begin{array}{l}\text { Dedicated } \\
\text { sample } \\
\text { reception room }\end{array}$} & \multirow{6}{*}{$\begin{array}{l}\text { 1. Exposure during sample } \\
\text { manipulation: } \\
\text { 2.Exposure during } \\
\text { vortex. } \\
\text { Sample spill in } \\
\text { BSC } \\
\text { Exposure during TNA } \\
\text { extraction } \\
\text { 5. Exposure during waste } \\
\text { disposal }\end{array}$} & \multicolumn{2}{|c|}{$\begin{array}{l}\text { Dedicated MDL for } \\
\text { SARS Cov2 testing }\end{array}$} & \multirow{23}{*}{$\begin{array}{l}\text { 1. Transcription } \\
\text { error: } 2 \text {. } \\
\text { Noncompliance of turn } \\
\text { time. } \\
\text { Unauthorized access to } \\
\text { samples. } \\
\text { 4. Sample loss or theft. }\end{array}$} \\
\hline & & \multicolumn{2}{|c|}{$\begin{array}{l}\mathrm{BSC} \mathrm{Cl} \mathrm{l} / \mathrm{Il} \text { for } \\
\text { sample sorting }\end{array}$} & & \multicolumn{2}{|c|}{$\begin{array}{l}\text { Safety cabinet (BSC } \\
\text { CL I) }\end{array}$} & \\
\hline & & \multicolumn{2}{|c|}{$\begin{array}{l}\text { Laboratory } \\
\text { access control }\end{array}$} & & \multicolumn{2}{|c|}{$\begin{array}{l}\text { Dedicated TNA } \\
\text { extraction system }\end{array}$} & \\
\hline & & \multicolumn{2}{|c|}{$\begin{array}{l}\text { Access control } \\
\text { refrigerators }\end{array}$} & & \multicolumn{2}{|c|}{$\begin{array}{l}\text { Real time PCR } \\
\text { system }\end{array}$} & \\
\hline & & \multicolumn{2}{|c|}{$\begin{array}{l}\text { Dedicated waste } \\
\text { collection bin }\end{array}$} & & \multicolumn{2}{|c|}{$\begin{array}{l}\text { Access control } \\
\text { freezers }\end{array}$} & \\
\hline & & & & & \multicolumn{2}{|c|}{$\begin{array}{l}\text { Dedicated waste } \\
\text { collection bin }\end{array}$} & \\
\hline \multirow[t]{7}{*}{$\begin{array}{l}\text { Administrative } \\
\text { control }\end{array}$} & & \multicolumn{2}{|c|}{$\begin{array}{l}\text { SOP for covid-19 } \\
\text { sample } \\
\text { reception }\end{array}$} & & \multicolumn{2}{|c|}{$\begin{array}{l}\text { MDL operation } \\
\text { manual }\end{array}$} & \\
\hline & & \multicolumn{2}{|c|}{$\begin{array}{l}\text { Laboratory } \\
\text { safety manual }\end{array}$} & & \multicolumn{2}{|c|}{$\begin{array}{l}\text { SOP for COVID-19 } \\
\text { sample inactivation }\end{array}$} & \\
\hline & & \multicolumn{2}{|c|}{$\begin{array}{l}\text { Waste disposal } \\
\text { manual }\end{array}$} & & \multicolumn{2}{|c|}{$\begin{array}{l}\text { SOP RT-PCR for } \\
\text { SARS-CoV-2 }\end{array}$} & \\
\hline & & \multicolumn{2}{|c|}{$\begin{array}{l}\text { Spill handling } \\
\text { procedure }\end{array}$} & & \multicolumn{2}{|c|}{$\begin{array}{l}\text { Waste disposal } \\
\text { manual }\end{array}$} & \\
\hline & & \multicolumn{2}{|c|}{$\begin{array}{l}\text { Hand washing } \\
\text { SOP }\end{array}$} & & \multicolumn{2}{|c|}{$\begin{array}{l}\text { Spill handling } \\
\text { procedure }\end{array}$} & \\
\hline & & \multicolumn{2}{|c|}{$\begin{array}{l}\text { SOP for facility } \\
\text { decontamination }\end{array}$} & & \multicolumn{2}{|c|}{ Hand washing SOP } & \\
\hline & & & & & \multicolumn{2}{|c|}{$\begin{array}{l}\text { SOP for facility } \\
\text { decontamination }\end{array}$} & \\
\hline \multirow[t]{10}{*}{$\begin{array}{l}\text { Operational } \\
\text { control }\end{array}$} & & $\begin{array}{l}\text { Cov } \\
\text { sam } \\
\text { recep } \\
\text { train }\end{array}$ & & & $\begin{array}{l}\text { Train } \\
\text { CoV- } \\
\text { testir }\end{array}$ & $\begin{array}{l}\text { ig on SARS- } \\
\text { RT-PCR }\end{array}$ & \\
\hline & & $\begin{array}{l}\text { Trair } \\
\text { use }\end{array}$ & g on PPE & & $\begin{array}{l}\text { Train } \\
\text { donn }\end{array}$ & $\begin{array}{l}\text { g on PPE } \\
\text { g and doffing }\end{array}$ & \\
\hline & & $\begin{array}{l}\text { Enha } \\
\text { clear } \\
\text { protc }\end{array}$ & & & $\begin{array}{l}\text { Enha } \\
\text { protc }\end{array}$ & $\begin{array}{l}\text { ced cleaning } \\
\text { ol }\end{array}$ & \\
\hline & & $\begin{array}{l}\text { Enha } \\
\text { disp }\end{array}$ & $\begin{array}{l}\text { ced waste } \\
\text { al }\end{array}$ & & $\begin{array}{l}\text { Enha } \\
\text { disp }\end{array}$ & $\begin{array}{l}\text { ced waste } \\
\text { al }\end{array}$ & \\
\hline & & $\begin{array}{l}\text { Rout } \\
\text { insp } \\
\text { facil }\end{array}$ & $\begin{array}{l}\text { tion of the } \\
\text { tion }\end{array}$ & & $\begin{array}{l}\text { Rout } \\
\text { of th }\end{array}$ & $\begin{array}{l}\text { e inspection } \\
\text { facility }\end{array}$ & \\
\hline & & PPE & $\begin{array}{l}\text { Reusable } \\
\text { lab coat }\end{array}$ & & PPE & (Disposable) & \\
\hline & & & $\begin{array}{l}\text { Face } \\
\text { mask } \\
\text { (ASTM } \\
\text { level 2), }\end{array}$ & & & $\begin{array}{l}\text { Face mask } \\
\text { (N 95 or } \\
\text { equivalent), }\end{array}$ & \\
\hline & & & $\begin{array}{l}\text { Nitrile } \\
\text { gloves, }\end{array}$ & & & $\begin{array}{l}\text { Nitrile } \\
\text { gloves, }\end{array}$ & \\
\hline & & & $\begin{array}{l}\text { Lab } \\
\text { coat, }\end{array}$ & & & $\begin{array}{l}\text { Full sleeve } \\
\text { lab coat } \\
\text { (AAMI level } \\
\text { 3) }\end{array}$ & \\
\hline & & & Goggle & & & Goggle, & \\
\hline
\end{tabular}

Page 7/9 
Table 2: Statistics of samples received, rejected, tested and turnaround time for 38,377 COVID-19 samples received from February 1 to $17^{\text {th }}$ September at Hospital for Tropical Diseases, Ho Chi Minh City Vietnam.

\begin{tabular}{|c|c|c|c|c|}
\hline \multirow[t]{2}{*}{ Month } & \multirow{2}{*}{$\begin{array}{l}\text { Sample received } \\
\text { (n) }\end{array}$} & \multirow{2}{*}{$\begin{array}{l}\text { Sample rejection } \\
\%(n)\end{array}$} & \multirow{2}{*}{$\begin{array}{l}\text { Outbreak sample } \\
\%(n)\end{array}$} & \multirow{2}{*}{$\begin{array}{l}\text { Tumaround time } \\
\text { mean } \pm \text { SD day }\end{array}$} \\
\hline & & & & \\
\hline February & 115 & $0(0)$ & 0 & $1.3 \pm 0.49$ \\
\hline March & 10833 & $0(0)$ & 70.8 (7667) & $3.9 \pm 1.91$ \\
\hline April & 8048 & $0(0)$ & $52.6(4237)$ & $2.4 \pm 1.38$ \\
\hline May & 906 & $0(0)$ & 0 & $2.3 \pm 0.88$ \\
\hline June & 529 & $1.2(11)$ & 0 & $2.4 \pm 2.13$ \\
\hline July & 5615 & $1.4(104)$ & $93.1(5226)$ & $5.48 \pm 3.91$ \\
\hline August & 11204 & $1.6(178)$ & 80.9 (9067) & $6.2 \pm 2.98$ \\
\hline September & 1127 & $0.2(2)$ & 0 & $2.9 \pm 1.11$ \\
\hline
\end{tabular}

\section{Figures}




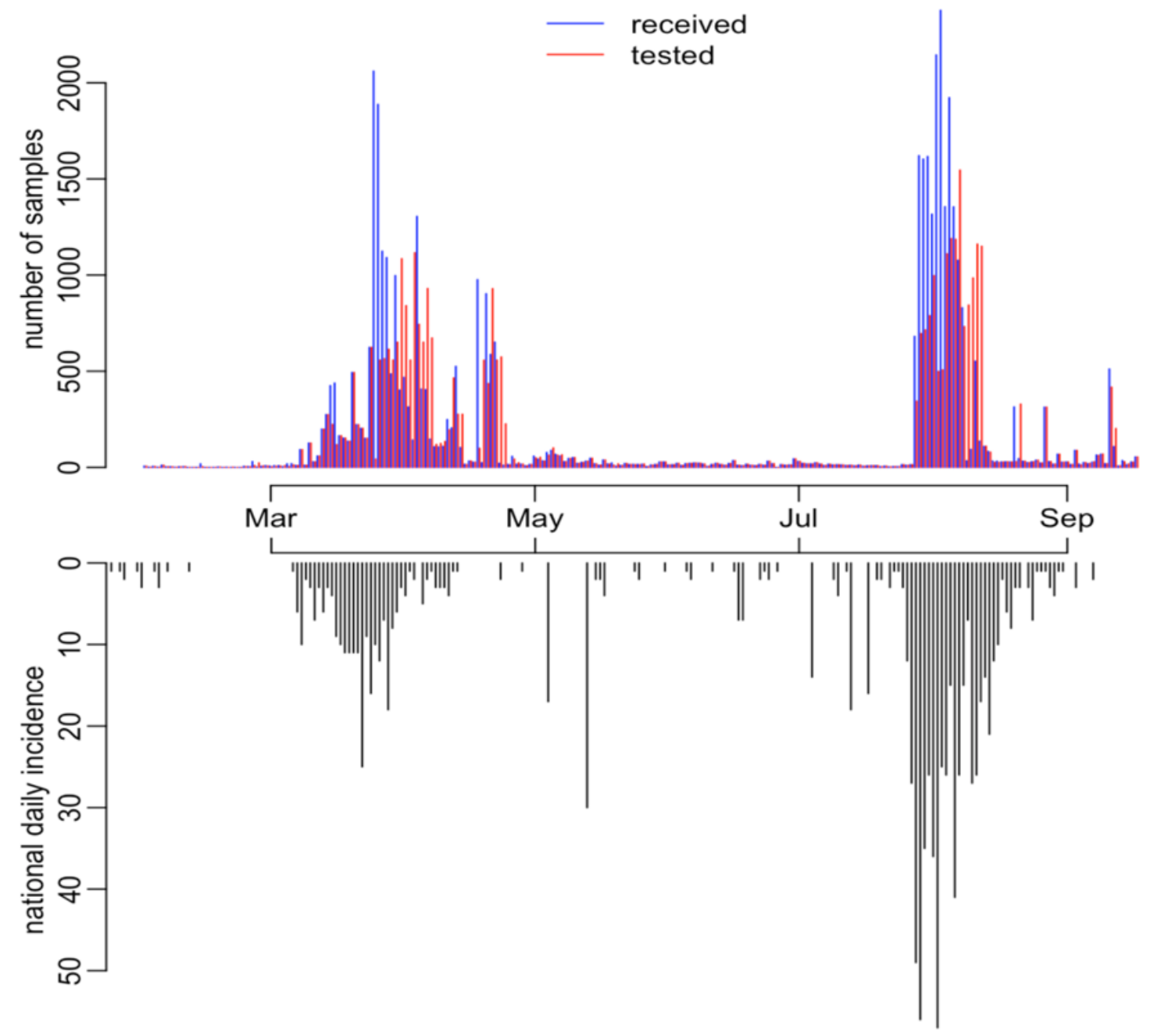

Figure 1

Number of received (blue) and tested (red) samples per day at HTD (top) and daily incidence of confirmed COVID-19 cases in Vietnam (bottom, reversed) over the study period. 